\title{
Effect of Different Plant Densities and Mulches on Growth and Yield of Mango (Mangifera indica L.) cv. Alphonso
}

\author{
B.S. Sagar*, S.I. Athani, S. Raghavendra, J.B. Gopali, Kulapati Hipparagi, \\ T.B. Allolli, Revanappa and Mallikarjun Awati \\ Department of Horticulture, College of Horticulture, University of Horticultural Sciences, \\ Bagalkot, 587-104 (Karnataka), India \\ *Corresponding author
}

\begin{tabular}{|l|}
\hline Keyw ord s \\
Different density, \\
Mulching, Growth \\
and yield \\
\hline Article Info \\
\hline Accepted: \\
18 May 2019 \\
Available Online: \\
10 June 2019 \\
\hline
\end{tabular}

\section{A B S T R A C T}

High density planting is a highly efficient and advanced production system of fruit cultivation. High yield and good fruit quality can be achieved with a high density orchard in guava when the orchard has good light distribution throughout the tree canopy and there is a balance between vegetative growth and cropping. To know the effect of high density planting and different mulches on growth and yield of mango (Mangifera indica L.) cv. Alphonso was undertaken at Regional Horticulture Research and Extension Centre, Dharwad (University of Horticultural Sciences, Bagalkot) during May - 2016 to June 2018. The maximum incremental data of plant height $(29.96 \mathrm{~cm})$, plant spread (EastWest) of $32.82 \mathrm{~cm}$ was recorded in $\mathrm{D}_{4} \mathrm{M}_{3}(7.5 \times 5 \mathrm{~m}$ spacing with plastic mulch) and the maximum increment of plant girth $(1.20 \mathrm{~cm})$ were recorded in $\mathrm{D}_{2} \mathrm{M}_{2}(5 \times 2.5 \mathrm{~m}$ spacing with straw mulch). The treatment $\mathrm{D}_{2} \mathrm{M}_{3}(5 \times 2.5 \mathrm{~m}$ spacing with plastic mulch) recorded the maximum plant spread of $30.90 \mathrm{~cm}$ (North-South), tertiary branches of 26.44 was found maximum in the treatment $\mathrm{D}_{4} \mathrm{M}_{1}$, maximum number of fruits per plant of 52.97 was recorded in $\mathrm{D}_{3} \mathrm{M}_{3}$ and highest yield per plant $(14.79 \mathrm{~kg})$ was recorded in $\mathrm{D}_{3} \mathrm{M}_{3}$. Whereas, the treatment $\mathrm{D}_{1} \mathrm{M}_{3}(2.5 \times 2.5 \mathrm{~m}$ spacing with plastic mulch) recorded the maximum canopy volume $\left(1.33 \mathrm{~cm}^{3}\right)$. Whereas, the highest number of primary branches of 4.33 was found in $\mathrm{D}_{2} \mathrm{M}_{2}$ and secondary branches (8.83) were recorded in the treatment $\mathrm{D}_{4} \mathrm{M}_{3}(5.0 \mathrm{x}$ $2.5 \mathrm{~m}$ spacing in control). The maximum yield per hectare (13.56) was recorded in $\mathrm{D}_{1} \mathrm{M}_{3}$ (2.5 x $2.5 \mathrm{~m}$ spacing with no mulch).

\section{Introduction}

Mango (Mangifera indica L) is an important and king of fruits in India known for its taste and Alphonso is one of the most expensive varieties of mango and is grown mainly in the western part of India including Sindhudurg, Ratnagiri and Raigad districts of Maharashtra and in the Konkan region of India. Alphonso is generally referred to as 'Hapus' in Maharashtra and Gujarat, also known as Appus, Badami, Gundu and Khader. It is used to make sweets, candies and smoothies and mango drinks. Fruits are orange-yellow in colour, medium-sized and oval/oblique in shape. The high density planting technology is the most viable proposition to increase the productivity by dwarf tree canopy and for 
efficient and profitable land use. Its basic function is to confine the exploitation zone of the plant with regard to light, water and nutrients, so that highest total yield potential can be realized in the smallest possible area. The main aim of high density planting is to produce more and more from unit area, from one species, in order to make the venture of tropical fruit production more remunerative and sustainable. Mulching is the process or practice of covering the soil/ground to make more favourable condition for plant growth, development and efficient crop production. According to other mulches plastic mulches are completely impermeable to water; therefore, it prevents direct evaporation of moisture from the soil and thus it reduces the water losses and soil erosion over the surface. Plastic film with its moisture barrier properties does not allow the soil moisture to escape water that evaporates from the soil surface under mulch film, condenses on the lower surface of the film and falls back as droplets. Thus moisture is preserved for several days and increases the period between two irrigations (Anonymous, 2014 and Biswas et al., 2015).

\section{Materials and Methods}

The present investigation of Studies on high density planting in mango (Mangifera indica L.) cv. Alphonso was carried out in Regional Horticulture Research and Extension Centre, Dharwad (University of Horticultural Sciences, Bagalkot) during May - 2016 to June - 2018. The material used, techniques adopted and observations recorded during the course of the investigation are presented in this chapter. Five year old mango orchard cv. Alphonso established during 2011 was selected for the experiment. The pruning was done after harvesting of fruits in 2016 and 2017. Three different mulches were used viz., $\mathrm{M}_{1}$ (no mulch), $\mathbf{M}_{2}$ (straw) and $\mathbf{M}_{3}$ (polythene mulch). Four different densities like $2.5 \times 2.5$ m (1600 plants/ ha), $5.0 \times 2.5 \mathrm{~m}$ (800 plants/ ha), $5.0 \times 5.0 \mathrm{~m}$ (400 plants/ ha) and $7.5 \times 5.0$ m (267 plants/ ha). Each treatment was replicated three times and four plants were chosen from each replication. The experiment was laid out in two Factorial Randomized Block Design. Growth parameters recorded during this study viz., plant height $(\mathrm{cm})$, stem girth $(\mathrm{mm})$, plant spread in both directions North-South and East-West (cm), canopy volume $\left(\mathrm{m}^{3}\right)$, number of primary branches, number of secondary branches and number of tertiary branches were measured at 60 days interval after imposition of treatments, in four representative plants in each treatment and average was calculated. For all the vegetative parameters the final growth and incremental growth is given. The growth increment was recorded by calculating the difference occurred after imposing of treatment to harvesting and given in results and discussed. Yield parameters viz., number of fruits harvested/plant, fruit yield ( $\mathrm{kg} /$ plant), fruit yield (tones/ ha) were recorded at the harvesting time.

\section{Results and Discussion}

\section{Vegetative parameters}

\section{Plant height (cm)}

From the pooled data of both seasons, it is recorded that the increment in plant height was varied significantly among the different planting densities. The increment in plant height was found maximum in the spacing 2.5 x $2.5 \mathrm{~m}(23.56 \mathrm{~cm})$ which was followed by the plants spaced at $5.0 \times 2.5 \mathrm{~m}(21.10 \mathrm{~cm})$ whereas, the minimum increment was recorded in $5.0 \times 5.0 \mathrm{~m}(18.08 \mathrm{~cm})$. With respect to the different mulches, plastic mulch recorded the maximum plant height increment $(26.41 \mathrm{~cm})$ which was followed by straw mulch $(21.22 \mathrm{~cm})$ while the minimum increment was noticed in the control (14.76 
$\mathrm{cm})$. In interaction effect of spacing and pruning, significant differences were recorded in the height increment of the plant. The highest plant height increment was recorded in $\mathrm{D}_{4} \mathrm{M}_{3}(29.96 \mathrm{~cm})$ which was followed by $\mathrm{D}_{1} \mathrm{M}_{3}(29.20 \mathrm{~cm})$ and the lowest was recorded in $\mathrm{D}_{4} \mathrm{M}_{1}(12.21 \mathrm{~cm})$ (Table 1).

\section{Plant girth (cm)}

From the pooled data of both seasons, the increment in plant girth was varied significantly among the different planting densities and mulching. The increment in plant girth was found maximum in $5.0 \times 2.5 \mathrm{~m}$ spacing $(0.96 \mathrm{~cm})$, which was followed by 7.5 $\mathrm{x} 5.0 \mathrm{~m}(0.88 \mathrm{~cm})$ whereas, the minimum increment in plant girth was noticed in $2.5 \mathrm{x}$ $2.5 \mathrm{~m}(0.79 \mathrm{~cm})$ which was on par with $5.0 \mathrm{x}$ $5.0 \mathrm{~m}(0.79 \mathrm{~cm})$. Different mulches showed significant difference, increment in plant girth was found maximum in plastic mulch $(1.07 \mathrm{~cm})$ which was on par with Straw mulch $(0.99 \mathrm{~cm})$ and the minimum was recorded in control $(0.54 \mathrm{~cm})$. In interaction effect of spacing and mulching, the increment in plant girth was found maximum in $\mathrm{D}_{2} \mathrm{M}_{2}(1.20 \mathrm{~cm})$ which was on par with $\mathrm{D}_{4} \mathrm{M}_{3}(1.14 \mathrm{~cm}), \mathrm{D}_{3} \mathrm{M}_{3}$ $(1.10 \mathrm{~cm})$ and $\mathrm{D}_{2} \mathrm{M}_{3}(1.09 \mathrm{~cm})$. Whereas, the minimum increment in plant girth was found in $\mathrm{D}_{1} \mathrm{M}_{1}(0.45 \mathrm{~cm})$.

\section{Plant spread East- West (cm)}

Pooled data of two seasons showed the highest plant spread (East-West) in the plants spaced at $7.5 \times 5.0 \mathrm{~m}(27.28 \mathrm{~cm})$ which was followed by $5.0 \times 5.0 \mathrm{~m}(25.69 \mathrm{~cm})$ and the minimum plant spread (East-West) increment was recorded in $2.5 \times 2.5 \mathrm{~m}(22.63 \mathrm{~cm})$. Different mulches showed significant difference, the maximum plant spread (East-West) increment was recorded in plastic mulch $(28.69 \mathrm{~cm})$ which was followed by straw mulch $(25.07$ $\mathrm{cm}$ ) and the minimum plant spread (EastWest) increment was recorded in control
$(19.98 \mathrm{~cm})$. Interaction data revealed the maximum plant spread (East-West) increment was recorded in $\mathrm{D}_{4} \mathrm{M}_{3}(32.82 \mathrm{~cm})$ which was followed by $\mathrm{D}_{3} \mathrm{M}_{3}(28.68 \mathrm{~cm}), \mathrm{D}_{4} \mathrm{M}_{2}(27.94$ $\mathrm{cm})$ and $\mathrm{D}_{2} \mathrm{M}_{3}(27.14 \mathrm{~cm})$. While the minimum plant spread (East-West) increment was recorded in $\mathrm{D}_{2} \mathrm{M}_{1}(17.98 \mathrm{~cm})$.

\section{Plant spread North- South (cm)}

Pooled data of two seasons showed, the maximum plant spread (North-South) was recorded in treatments $5.0 \times 5.0 \mathrm{~m}(27.48 \mathrm{~cm})$ and $7.5 \times 5.0 \mathrm{~m}(27.48 \mathrm{~cm})$ which was on par with the plants spaced at $5.0 \times 2.5 \mathrm{~m}(26.51$ $\mathrm{cm}$ ) and the minimum plant spread (NorthSouth) increment was recorded in $2.5 \times 2.5 \mathrm{~m}$ $(25.12 \mathrm{~cm})$. Different mulches showed significant difference, the maximum plant spread (North-South) increment was recorded in plastic mulch $(31.03 \mathrm{~cm})$ which was followed by straw mulch $(27.95 \mathrm{~cm})$ and the minimum plant spread (North-South) increment was recorded in control $(20.96 \mathrm{~cm})$. Interaction data revealed the maximum plant spread (North-South) increment was recorded in $\mathrm{D}_{2} \mathrm{M}_{3}(30.90 \mathrm{~cm})$ which was on par with $\mathrm{D}_{1} \mathrm{M}_{3}(30.12 \mathrm{~cm}), \mathrm{D}_{3} \mathrm{M}_{2}(29.55 \mathrm{~cm}), \mathrm{D}_{3} \mathrm{M}_{3}$ $(29.02 \mathrm{~cm})$ and $\mathrm{D}_{2} \mathrm{M}_{2}(28.17 \mathrm{~cm})$. While the minimum plant spread (North-South) increment was recorded in $\mathrm{D}_{1} \mathrm{M}_{1}(18.30 \mathrm{~cm})$ and $\mathrm{D}_{4} \mathrm{M}_{3}(18.30 \mathrm{~cm})$ (Table 2).

\section{Canopy volume $\left(\mathrm{m}^{3}\right)$}

From the pooled data of 2016-18, the highest canopy volume increment $\left(1.23 \mathrm{~m}^{3}\right)$ was recorded in the treatment $7.5 \times 5.0 \mathrm{~m}$ which was followed by the treatments $2.5 \times 2.5 \mathrm{~m}$ $\left(1.06 \mathrm{~m}^{3}\right)$ and $5.0 \times 5.0 \mathrm{~m}\left(1.06 \mathrm{~m}^{3}\right)$. Whereas, the lowest canopy volume increment $\left(1.01 \mathrm{~m}^{3}\right)$ was recorded in the treatment $5 \times 2.5 \mathrm{~m}$. Different mulches showed significant difference, the highest canopy volume $\left(\mathrm{m}^{3}\right)$ increment $\left(1.39 \mathrm{~m}^{3}\right)$ was recorded in the treatment plastic mulch which was followed 
by the treatment straw mulch $\left(1.11 \mathrm{~m}^{3}\right)$ and the lowest canopy volume increment $\left(0.77 \mathrm{~m}^{3}\right)$ was recorded in control. Interaction data showed that the highest canopy volume increment $\left(1.72 \mathrm{~m}^{3}\right)$ was recorded in the treatment $\mathrm{D}_{4} \mathrm{M}_{3}$ which was followed by the treatment $\mathrm{D}_{1} \mathrm{M}_{3}\left(1.33 \mathrm{~m}^{3}\right)$ and the lowest canopy volume increment $\left(0.72 \mathrm{~m}^{3}\right)$ was recorded in the treatment $\mathrm{D}_{2} \mathrm{M}_{1}$ which was on par with $\mathrm{D}_{1} \mathrm{M}_{1}\left(0.76 \mathrm{~m}^{3}\right)$ and $\mathrm{D}_{3} \mathrm{M}_{1}\left(0.80 \mathrm{~m}^{3}\right)$.

\section{Number of primary, secondary and tertiary branches in mango cv. Alphonso}

The highest number of primary branches (4.22) was recorded in the plants spaced at 5.0 $\mathrm{x} 2.5 \mathrm{~m}$ which was followed by the treatment $2.5 \times 2.5 \mathrm{~m} \mathrm{(3.61)}$ and the lowest was recorded in the treatment $5.0 \times 5.0 \mathrm{~m}(3.07)$.

The highest number of primary branches was recorded in plastic mulch (3.61) but the results were found non-significant among the treatments. Whereas, in interaction of spacing and mulching, the highest number of primary branches (4.33) was recorded in the treatment $\mathrm{D}_{2} \mathrm{M}_{2}$ which was on par with the treatment $\mathrm{D}_{2} \mathrm{M}_{3}$ (4.25) and $\mathrm{D}_{2} \mathrm{M}_{1}$ (4.08) whereas, the lowest was recorded in the treatment $\mathrm{D}_{3} \mathrm{M}_{3}$ (3.00) which was on par with $\mathrm{D}_{3} \mathrm{M}_{2}$ (3.08), $\mathrm{D}_{3} \mathrm{M}_{1}$ (3.14) and $\mathrm{D}_{4} \mathrm{M}_{2}$ (3.16).

The highest number of secondary branches (8.64) was recorded in the plants spaced at 5.0 x $2.5 \mathrm{~m}$ which was followed by the treatment $2.5 \times 2.5 \mathrm{~m}(7.86)$ and the lowest was recorded in the treatment $5.0 \times 5.0 \mathrm{~m}$ (5.85). The highest number of secondary branches was recorded in plastic mulch (7.69) which was followed by straw mulch (7.38) and the lowest was recorded in control (7.36). Whereas, in interaction of spacing and mulching, the highest number of secondary branches (8.83) was recorded in the treatment $\mathrm{D}_{2} \mathrm{M}_{3}$ which was on par with the treatment $\mathrm{D}_{2} \mathrm{M}_{1}$ (8.66) and $\mathrm{D}_{2} \mathrm{M}_{2}$ (8.50) whereas, the lowest was recorded in the treatment $D_{3} M_{1}$ (5.62) which was on par with $\mathrm{D}_{3} \mathrm{M}_{2}$ (5.68).

The highest number of tertiary branches (25.01) was recorded in the plants spaced at $7.5 \times 5.0 \mathrm{~m}$ which was followed by the treatment $5.0 \times 2.5 \mathrm{~m}$ (24.65) and the lowest was recorded in the treatment $5.0 \times 5.0 \mathrm{~m}$ (21.27). The highest number of tertiary branches was recorded in control (24.40) which was on par with plastic mulch (23.87) and the lowest was recorded in straw mulch (22.89). Whereas, in interaction of spacing and mulching, the highest number of tertiary branches (26.33) was recorded in the treatment $\mathrm{D}_{4} \mathrm{M}_{1}$ which was on par with the treatment $\mathrm{D}_{2} \mathrm{M}_{3}$ (26.20) and $\mathrm{D}_{2} \mathrm{M}_{1}$ (26.08) whereas, the lowest was recorded in the treatment $\mathrm{D}_{3} \mathrm{M}_{3}$ (20.16).

\section{Effect of different plant densities and different mulches on yield parameters}

Yield parameters like number of fruits per plant, yield ( $\mathrm{kg} /$ plant) and yield (t/ha) were recorded at the time of harvesting in both the seasons of 2016-17 and 2017-18. Yield parameters as influenced by different plant densities, different mulches and their interaction effect differed significantly and furnished in Table 3.

\section{Number of fruits per plant}

Pooled data (2016-18) of both the seasons was recorded in Table 3. The maximum number of fruits per plant was recorded in the plants spaced at $5.0 \times 5.0 \mathrm{~m}(46.27)$ on par with the spacing $7.5 \times 5.0 \mathrm{~m}(45.55)$ and minimum number of fruits per plant was recorded in 2.5 x $2.5 \mathrm{~m}$ (29.75). With respect to different mulches the the maximum number of fruits per plant was recorded in plastic mulch (44.97) which was followed by straw mulch (41.00) and the minimum number of fruits per plant was recorded in control (33.19). 
Table.1 Effect of different plant density and different mulches on vegetative growth parameters of mango cv. Alphonso pooled incremental data of both seasons (2016-18)

\begin{tabular}{|c|c|c|c|c|c|c|c|c|c|}
\hline \multirow[t]{3}{*}{ Treatments } & \multicolumn{9}{|c|}{ Vegetative growth parameters } \\
\hline & \multicolumn{3}{|c|}{ Plant height (cm) } & \multicolumn{3}{|c|}{ Plant girth $(\mathrm{cm})$} & \multicolumn{3}{|c|}{$\begin{array}{l}\text { Plant spread (cm) (East- } \\
\text { West) }\end{array}$} \\
\hline & \multicolumn{3}{|c|}{$\begin{array}{l}\text { Season } 1 \text { Season } 2 \text { P } \\
(\mathbf{2 0 1 6 - 1 7 )})(\mathbf{2 0 1 7 - 1 8 )})\end{array}$} & \multicolumn{3}{|c|}{\begin{tabular}{l|ll} 
Season 1 & Season 2 & Pooled \\
$(2016-17)$ & $(2017-18)$ & $(2016-18)$
\end{tabular}} & \multicolumn{3}{|c|}{$\begin{array}{lll}\text { Season } 1 & \text { Season } 2 & \text { Pooled } \\
(2016-17) & (2017-18) & (2016-18)\end{array}$} \\
\hline \multicolumn{10}{|c|}{ Spacing (D) } \\
\hline $\mathbf{D}_{1}$ & 26.12 & 21.33 & 23.56 & 0.90 & 0.68 & 0.79 & 26.41 & 18.84 & 22.63 \\
\hline $\mathbf{D}_{2}$ & 25.23 & 17.00 & 21.10 & 1.04 & 0.94 & 0.96 & 25.78 & 19.65 & 22.72 \\
\hline $\mathbf{D}_{\mathbf{3}}$ & 20.57 & 15.60 & 18.08 & 0.74 & 0.83 & 0.79 & 26.19 & 25.19 & 25.69 \\
\hline $\mathbf{D}_{4}$ & 22.68 & 18.19 & 20.44 & 0.85 & 0.91 & 0.88 & 30.36 & 24.20 & 27.28 \\
\hline S.Em \pm & 0.41 & 0.29 & 0.49 & 0.04 & 0.05 & 0.03 & 0.26 & 0.43 & 0.44 \\
\hline CD@5\% & 1.19 & 0.84 & 1.43 & 0.12 & 0.12 & 0.10 & 0.77 & 1.27 & 1.29 \\
\hline \multicolumn{10}{|c|}{ Mulching (M) } \\
\hline $\mathbf{M}_{1}$ & 16.61 & 13.17 & 14.76 & 0.57 & 0.51 & 0.54 & 22.29 & 17.67 & 19.98 \\
\hline $\mathbf{M}_{2}$ & 24.42 & 18.03 & 21.22 & 0.98 & 0.99 & 0.99 & 27.72 & 22.41 & 25.07 \\
\hline $\mathbf{M}_{3}$ & 29.92 & 22.89 & 26.41 & 1.10 & 1.03 & 1.07 & 31.54 & 25.83 & 28.69 \\
\hline S.Em \pm & 0.35 & 0.25 & 0.42 & 0.04 & 0.05 & 0.04 & 0.23 & 0.37 & 0.38 \\
\hline CD@5\% & 1.03 & 0.72 & 1.24 & 0.14 & 0.11 & 0.13 & 0.66 & 1.10 & 1.12 \\
\hline \multicolumn{10}{|c|}{ Interaction } \\
\hline $\mathbf{D}_{1} \mathbf{M}_{1}$ & 19.07 & 15.53 & 17.30 & 0.57 & 0.33 & 0.45 & 22.46 & 16.12 & 19.28 \\
\hline $\mathbf{D}_{1} \mathbf{M}_{2}$ & 27.10 & 21.23 & 24.17 & 1.19 & 0.76 & 0.98 & 25.64 & 19.33 & 22.49 \\
\hline $\mathbf{D}_{1} \mathbf{M}_{3}$ & 32.19 & 26.22 & 29.20 & 0.95 & 0.95 & 0.95 & 31.14 & 21.08 & 26.12 \\
\hline $\mathbf{D}_{2} \mathbf{M}_{1}$ & 19.71 & 12.32 & 16.01 & 0.77 & 0.62 & 0.69 & 20.54 & 15.42 & 17.98 \\
\hline $\mathbf{D}_{2} \mathbf{M}_{2}$ & 26.44 & 18.67 & 22.54 & 1.16 & 1.22 & 1.20 & 26.93 & 19.12 & 23.03 \\
\hline $\mathbf{D}_{2} \mathbf{M}_{3}$ & 29.53 & 20.00 & 24.76 & 1.18 & 0.99 & 1.09 & 29.86 & 24.42 & 27.14 \\
\hline $\mathbf{D}_{3} \mathbf{M}_{1}$ & 14.48 & 12.55 & 13.51 & 0.44 & 0.51 & 0.48 & 22.56 & 20.58 & 21.57 \\
\hline $\mathbf{D}_{3} \mathbf{M}_{2}$ & 23.56 & 14.54 & 19.05 & 0.65 & 0.94 & 0.80 & 27.11 & 26.54 & 26.82 \\
\hline $\mathbf{D}_{3} \mathbf{M}_{3}$ & 23.68 & 19.70 & 21.70 & 1.15 & 1.04 & 1.10 & 28.90 & 28.45 & 28.68 \\
\hline $\mathbf{D}_{4} \mathbf{M}_{1}$ & 13.16 & 11.27 & 12.21 & 0.49 & 0.56 & 0.53 & 23.61 & 18.56 & 21.09 \\
\hline $\mathbf{D}_{4} \mathbf{M}_{2}$ & 20.60 & 17.67 & 19.14 & 0.91 & 1.05 & 0.98 & 31.21 & 24.66 & 27.94 \\
\hline $\mathbf{D}_{4} \mathbf{M}_{3}$ & 34.28 & 25.63 & 29.96 & 1.14 & 1.13 & 1.14 & 36.27 & 29.37 & 32.82 \\
\hline S.Em \pm & 0.70 & 0.49 & 0.85 & 0.05 & 0.04 & 0.04 & 0.45 & 0.75 & 0.76 \\
\hline CD@5\% & 2.06 & 1.45 & 2.48 & 0.17 & 0.13 & 0.12 & 1.33 & 2.20 & 2.23 \\
\hline $\begin{array}{l}\text { D1- } 2.5> \\
\text { D2- } 5.0>\end{array}$ & $\begin{array}{l}\times 2.5 \mathrm{~m}(16 \\
\times 2.5 \mathrm{~m}(80\end{array}$ & $\begin{array}{l}\text { plants/ha) } \\
\text { lants/ha) }\end{array}$ & & $\begin{array}{l}M_{1}-\text { Control } \\
M_{2} \text { - Straw mo }\end{array}$ & & & 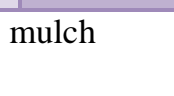 & & \\
\hline
\end{tabular}

D3- $5.0 \times 5.0 \mathrm{~m}(400$ plants/ ha $)$

D4- $7.5 \times 5.0 \mathrm{~m}(267$ plants/ ha) 
Table.2 Effect of different plant density and different mulches on vegetative growth parameters of mango cv. Alphonso pooled incremental data of both seasons (2016-18)

\section{Treatments}

\begin{tabular}{|c|c|c|}
\hline \multicolumn{3}{|c|}{$\begin{array}{l}\text { Plant spread (cm) (North- } \\
\text { South) }\end{array}$} \\
\hline $\begin{array}{l}\text { eason } 1 \\
016-17)\end{array}$ & $\begin{array}{c}\text { Season } 2 \\
(2017-18)\end{array}$ & $\begin{array}{c}\text { Pooled } \\
(2016-18)\end{array}$ \\
\hline
\end{tabular}

\section{Vegetative growth parameter}

\section{Canopy volume $\left(\mathrm{m}^{3}\right)$}

\begin{tabular}{|c|c|c|c|c|c|}
\hline $\begin{array}{c}\text { Season 1 } \\
(2016-17)\end{array}$ & $\begin{array}{c}\text { Season } 2 \\
(2017-18)\end{array}$ & $\begin{array}{c}\text { Pooled } \\
(2016-18)\end{array}$ & $\begin{array}{c}\text { Primary } \\
\text { branches }\end{array}$ & $\begin{array}{c}\text { Secondary } \\
\text { branches }\end{array}$ & $\begin{array}{c}\text { Tertiary } \\
\text { branches }\end{array}$ \\
\hline
\end{tabular}
Spacing (D)

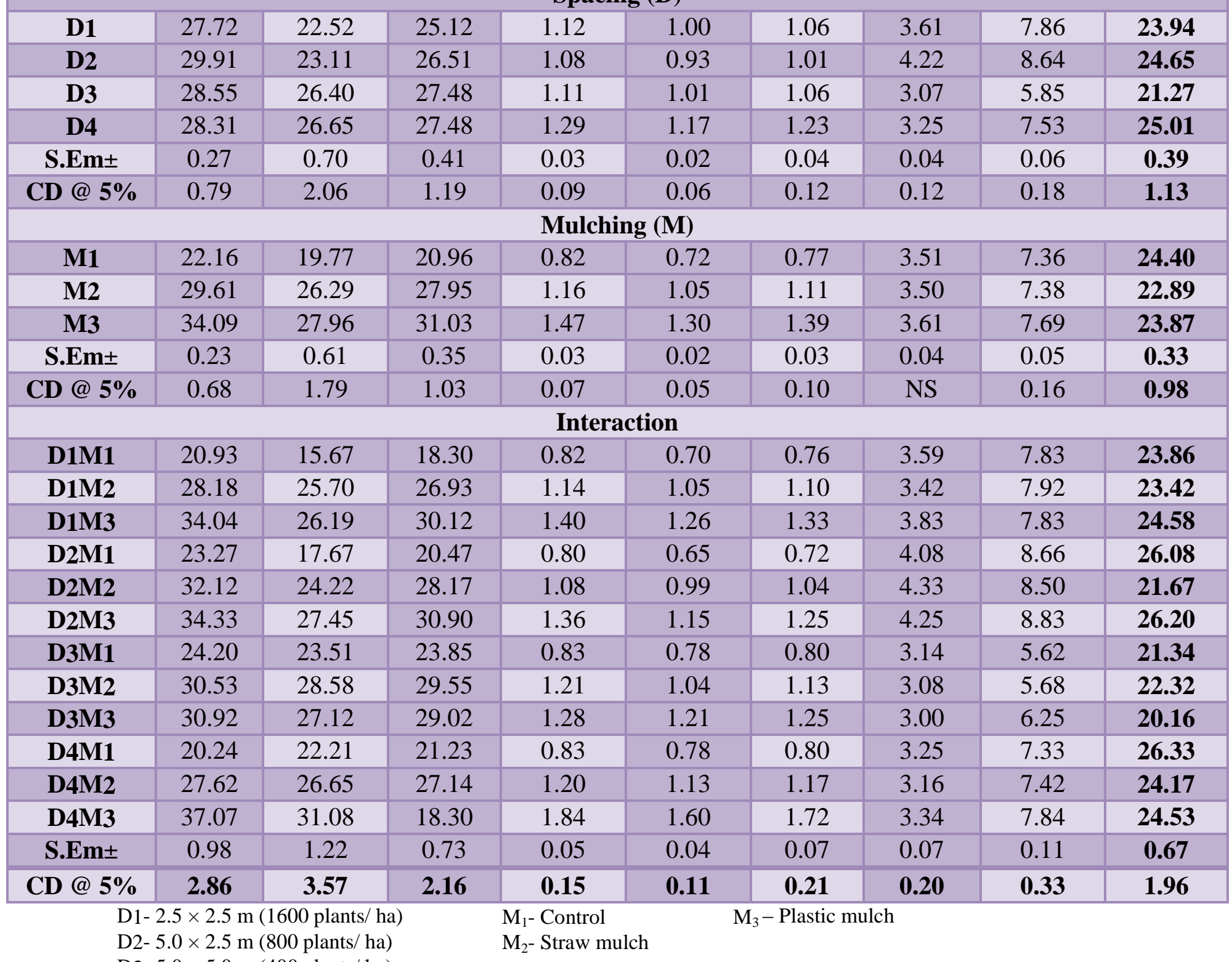

D3- $5.0 \times 5.0 \mathrm{~m}(400$ plants/ ha)

D4- $7.5 \times 5.0 \mathrm{~m}(267$ plants/ ha $)$

\section{Number of branches}

Secondary Tertiary anches

\section{Mulching (M)}


Table.3 Effect of different plant density and different mulches on yield parameters of mango cv. Alphonso (2016-18)

\begin{tabular}{|c|c|c|c|c|c|c|c|c|c|}
\hline \multirow[t]{3}{*}{ Treatments } & \multicolumn{3}{|c|}{$\begin{array}{c}\text { Number of fruits per } \\
\text { plant }\end{array}$} & \multicolumn{3}{|c|}{ Yield per plant (kg) } & \multicolumn{3}{|c|}{ Yield per hectare (t/ha) } \\
\hline & \multicolumn{2}{|c|}{ Season 1 Season 2} & \multirow{2}{*}{$\begin{array}{c}\text { Pooled } \\
(2016- \\
18)\end{array}$} & \multicolumn{2}{|c|}{ Season 1 Season 2} & \multirow{2}{*}{$\begin{array}{c}\text { Pooled } \\
\text { (2016- } \\
18)\end{array}$} & \multicolumn{2}{|c|}{ Season 1 Season 2} & \multirow{2}{*}{$\begin{array}{c}\text { Pooled } \\
\text { (2016- } \\
18)\end{array}$} \\
\hline & $\begin{array}{c}\text { (2016- } \\
\text { 17) }\end{array}$ & $\begin{array}{c}\text { (2017- } \\
18)\end{array}$ & & $\begin{array}{c}\text { (2016- } \\
\text { 17) }\end{array}$ & $\begin{array}{c}\text { (2017- } \\
18)\end{array}$ & & $\begin{array}{c}\text { (2016- } \\
\text { 17) }\end{array}$ & $\begin{array}{c}(2017- \\
18)\end{array}$ & \\
\hline \multicolumn{10}{|c|}{ Spacing (D) } \\
\hline $\mathbf{D}_{1}$ & 32.21 & 27.29 & 29.75 & 8.12 & 6.49 & 7.31 & 13.00 & 10.39 & 11.69 \\
\hline $\mathbf{D}_{2}$ & 43.95 & 30.66 & 37.31 & 11.31 & 7.67 & 9.49 & 9.04 & 6.14 & 7.55 \\
\hline $\mathbf{D}_{\mathbf{3}}$ & 52.26 & 41.28 & 46.27 & 14.03 & 10.87 & 12.45 & 5.61 & 4.35 & 4.97 \\
\hline $\mathbf{D}_{4}$ & 50.70 & 40.42 & 45.55 & 13.58 & 11.70 & 12.64 & 3.62 & 3.13 & 3.38 \\
\hline S.Em \pm & 0.72 & 0.54 & 0.48 & 0.14 & 0.14 & 0.20 & 0.13 & 0.08 & 0.19 \\
\hline CD@5\% & 2.11 & 1.57 & 1.40 & 0.42 & 0.40 & 0.59 & 0.39 & 0.23 & 0.55 \\
\hline \multicolumn{10}{|c|}{ Mulching (M) } \\
\hline $\mathbf{M}_{1}$ & 38.43 & 27.96 & 33.19 & 9.60 & 7.03 & 8.31 & 6.32 & 4.65 & 5.48 \\
\hline $\mathbf{M}_{2}$ & 45.42 & 36.57 & 41.00 & 12.04 & 9.58 & 10.82 & 7.98 & 6.35 & 7.17 \\
\hline $\mathbf{M}_{3}$ & 50.50 & 39.45 & 44.97 & 13.64 & 10.95 & 12.30 & 9.17 & 7.02 & 8.09 \\
\hline S.Em \pm & 0.62 & 0.46 & 0.41 & 0.12 & 0.12 & 0.17 & 0.11 & 0.07 & 0.16 \\
\hline CD@5\% & 1.83 & 1.36 & 1.21 & 0.37 & 0.36 & 0.51 & 0.33 & 0.20 & 0.48 \\
\hline \multicolumn{10}{|c|}{ Interaction } \\
\hline $\mathbf{D}_{1} \mathbf{M}_{1}$ & 27.29 & 21.73 & 24.50 & 6.45 & 5.09 & 5.77 & 10.32 & 8.14 & 9.23 \\
\hline $\mathbf{D}_{1} \mathbf{M}_{2}$ & 32.60 & 29.88 & 31.24 & 8.30 & 7.05 & 7.68 & 13.28 & 11.29 & 12.29 \\
\hline $\mathbf{D}_{1} \mathbf{M}_{3}$ & 36.74 & 30.26 & 33.49 & 9.62 & 7.34 & 8.49 & 15.39 & 11.74 & 13.56 \\
\hline $\mathbf{D}_{2} \mathbf{M}_{1}$ & 37.12 & 24.77 & 30.96 & 8.97 & 5.93 & 7.44 & 7.17 & 4.75 & 5.97 \\
\hline $\mathbf{D}_{2} \mathbf{M}_{2}$ & 44.44 & 32.01 & 38.22 & 11.57 & 8.05 & 9.81 & 9.26 & 6.44 & 7.85 \\
\hline $\mathbf{D}_{2} \mathbf{M}_{3}$ & 50.29 & 35.21 & 42.75 & 13.39 & 9.04 & 11.21 & 10.70 & 7.23 & 8.96 \\
\hline $\mathbf{D}_{3} \mathbf{M}_{1}$ & 47.12 & 31.72 & 39.43 & 12.03 & 8.03 & 10.03 & 4.81 & 3.21 & 4.01 \\
\hline $\mathbf{D}_{3} \mathbf{M}_{2}$ & 51.20 & 41.65 & 46.42 & 13.87 & 11.20 & 12.54 & 5.54 & 4.47 & 5.00 \\
\hline $\mathbf{D}_{3} \mathbf{M}_{3}$ & 58.45 & 47.48 & 52.97 & 16.17 & 13.40 & 14.79 & 6.46 & 5.35 & 5.90 \\
\hline $\mathbf{D}_{4} \mathbf{M}_{1}$ & 42.15 & 33.62 & 37.88 & 10.96 & 9.06 & 10.01 & 2.92 & 2.42 & 2.67 \\
\hline $\mathbf{D}_{4} \mathbf{M}_{2}$ & 53.42 & 42.75 & 48.09 & 14.45 & 12.03 & 13.24 & 3.85 & 3.21 & 3.53 \\
\hline $\mathbf{D}_{4} \mathbf{M}_{3}$ & 56.53 & 44.83 & 50.68 & 15.37 & 14.02 & 14.69 & 4.10 & 3.75 & 3.94 \\
\hline S.Em \pm & 1.25 & 0.93 & 0.82 & 0.25 & 0.29 & 0.35 & 0.23 & 0.14 & 0.33 \\
\hline CD @5\% & 3.65 & 2.72 & 2.42 & 0.73 & 0.86 & 1.02 & 0.67 & 0.40 & 0.96 \\
\hline $\begin{array}{l}\text { D1- } 2.5 \times \\
\text { D2- } 5.0 \times\end{array}$ & 1000 & ha) & & trol & & Thas & ch & & \\
\hline
\end{tabular}

D3- $5.0 \times 5.0 \mathrm{~m}(400$ plants/ ha)

D4- $7.5 \times 5.0 \mathrm{~m}(267$ plants/ ha $)$ 
Whereas in interaction the maximum number of fruits per plant was recorded in $\mathrm{D}_{3} \mathrm{M}_{3}$ (52.97) which was on par with the treatment $\mathrm{D}_{4} \mathrm{M}_{3}$ (50.68) and the minimum number of fruits per plant was recorded in $\mathrm{D}_{1} \mathrm{M}_{1}$ (24.50).

\section{Yield per plant (kg)}

The maximum yield per plant in the spacing $7.5 \times 5.0 \mathrm{~m}(12.64 \mathrm{~kg})$ which was on par with the spacing $5.0 \times 5.0 \mathrm{~m}(12.45 \mathrm{~kg})$ and the minimum yield per plant was recorded in the treatment $2.5 \times 2.5 \mathrm{~m}(7.31 \mathrm{~kg})$. Among the different mulches the maximum yield per plant was recorded in plastic mulch (12.30 $\mathrm{kg}$ ) which was followed by straw mulch $(10.82 \mathrm{~kg})$ and the minimum yield per plant was recorded in control $(8.31 \mathrm{~kg})$. Whereas in interaction the maximum yield per plant was recorded in $\mathrm{D}_{3} \mathrm{M}_{3}(14.79 \mathrm{~kg})$ which was on par with the treatment $\mathrm{D}_{4} \mathrm{M}_{3}(14.69 \mathrm{~kg})$ and the minimum yield per plant was recorded in $\mathrm{D}_{1} \mathrm{M}_{1}(5.77 \mathrm{~kg})$.

\section{Yield per hectare (t/ha)}

Pooled data (2016-18) of both the seasons showed highest yield per hectare in the plant spacing $2.5 \times 2.5 \mathrm{~m}(11.69 \mathrm{t} / \mathrm{ha})$ which was followed by the spacing $5.0 \times 2.5 \mathrm{~m}(7.55$ t/ha) and the minimum yield per hectare was recorded in the treatment $7.5 \times 5.0 \mathrm{~m}(3.38$ t/ha). Among the different mulches it showed significant difference with maximum yield per hectare was recorded in plastic mulch (8.09 t/ha) which was followed by straw mulch (7.17 t/ha) and the minimum yield per hectare was recorded in the treatment control (5.48 t/ha). The interactive effect of spacing and mulching showed positive effects, the treatment $\mathrm{D}_{1} \mathrm{M}_{3}(13.56 \mathrm{t} / \mathrm{ha})$ recorded the maximum yield per hectare which was followed by $\mathrm{D}_{1} \mathrm{M}_{2}(12.29 \mathrm{t} / \mathrm{ha})$ and $\mathrm{D}_{1} \mathrm{M}_{1}$ $(9.23 \mathrm{t} / \mathrm{ha})$ whereas, the minimum yield per hectare was recorded in the treatment $\mathrm{D}_{4} \mathrm{M}_{1}$ (2.67 t/ha).

\section{Vegetative growth}

Interactive effects of spacing and mulching revealed that, plants spaced at $7.5 \times 5.0 \mathrm{~m}$ with plastic mulch showed the highest plant height, plant girth, plant spread East- West, canopy volume whereas, control plants showed the highest number of tertiary branches in same spacing. Plants spaced at 5.0 $\mathrm{x} 2.5 \mathrm{~m}$ spacing with straw mulch recorded the highest number of primary branches. Whereas, plastic mulch showed the highest number of secondary branches in same spacing. With respect to incremental data the maximum plant height increment, plant spread East- West and canopy volume were recorded in the plants spaced at $7.5 \times 5.0 \mathrm{~m}$ with plastic mulch.

Plants spaced at $5.0 \times 2.5 \mathrm{~m}$ spacing with straw mulch showed the maximum plant girth whereas, plastic mulch recorded the maximum plant spread North- South direction in the same spacing. It may be attributed to the synergistic and interactive influence of spacing and black polyethylene mulch on the creation of a comparatively favourable environment (microclimate) and better moisture conservation, suppression of weed growth, etc., which might have resulted in comparatively better growth of plants than other combinations in conformity with Sharma and Singh (2006) ${ }^{[2]}$.

The water vapors that evaporate from the soil surface further trapped in the plastic and dropped again into the upper soil surface which increases soil moisture content in the root zone. Such an improvement in soil hydrothermal regime with mulching was also reported on several other tropical fruits by Dutta and Majumder (2009) ${ }^{[3]}$. Shirgure (2012) ${ }^{\text {[4] }}$ reported the highest increase in plant height with black polyethylene mulch. This is in conformity with Ghosh and Bauri (2003) in mango fruits cv. Himsagar. 


\section{Yield parameters}

Plants spaced at $5.0 \times 5.0 \mathrm{~m}$ with the use of plastic mulch recorded the maximum number of fruits per plant and fruit yield per plant. This may be due to polythene mulch responsible for reduced fertilizer leaching, increased water use efficiency and increase in organic matter induced more number of flowers per plant, high per cent fruit set which subsequently increase the number of fruits per plant which increased the yield per plant this in accordance with Sarolia and Bhardwaj $(2009)^{[5]}$.

Plants spaced at $2.5 \times 2.5 \mathrm{~m}$ spacing with plastic mulch increased the yield per hectare. This may be due to accommodation of more number of plants per unit area in closer spacing compared to wider spacing whereas, plastic mulch performed better in different densities compare to other treatments. The main benefit of mulching is to raise the soil temperature in planted zone, which promotes crop yield (Panwar et al., 2007) ${ }^{[6]}$. Increased macronutrient uptake with the use of mulching was also reported in mango (Dutta and Kundu 2012) ${ }^{[7]}$.

\section{References}

Anonymous 2014, Effect of mulch and irrigation level by drip on water use efficiency and yield of water melon. $10^{\text {th }}$ AGRESCO report, CAET, JAU, Junagadh.

Dutta, P and Kundu, D., 2009, Effect of mulching on post-harvest quality of Guava cv. L-49grown in red and laterite tract of West Bengal. Adv. Hort. Sci., 23(3):175-178.

Dutta, P and Majumder, D., 2009, Effect of mulching on post-harvest quality of Guava cv. L-49grown in red and laterite tract of West Bengal. Adv. Hort. Sci., 23(3):175-178.

Panwar, R., Singh, S. K., Singh, C. P. and Singh, P. K., 2007, Mango fruit yield and quality improvement through fertigation along with mulch. Indian J. Agrcltl. Sci., 77 (10): 680-684.

Sarolia, D. K and Bharadwaj, 2009, Evaluation of substrate dynamics for integrated nutrient management under high density planting of guava cv. Sardar. Indian J. Hort., 66 (4): 461-464.

Sharma, R. R., Singh, R. and Singh, D. S., 2006, Influence of pruning intensity on light penetration and leaf physiology in high-density orchards of mango trees. Fruits, 61: 117-123.

Shirgure, P. S., 2012, Sustainable Acid lime production and soil moisture conservation with different mulches. Agricultural Eng. Today, 36(3): 21-26.

\section{How to cite this article:}

Sagar, B.S., SI. Athani, S. Raghavendra, J.B. Gopali, Kulapati Hipparagi, T.B. Allolli, Revanappa and Mallikarjun Awati. 2019. Effect of Different Plant Densities and Mulches on Growth and Yield of Mango (Mangifera indica L.) cv. Alphonso. Int.J.Curr.Microbiol.App.Sci. 8(07): 3369-3377. doi: https://doi.org/10.20546/ijcmas.2019.806.400 